\section{Experimental evidence that microbial activity lowers the albedo of glaciers}

M. Musilova ${ }^{1,2 *}$, M. Tranter ${ }^{1}$, J.L. Bamber ${ }^{1}$ N. Takeuchi ${ }^{3}$, A.M. Anesio

\section{Abstract}

Darkening of glacier and ice sheet surfaces is an important positive feedback to increasing global temperatures. Deposition of impurities on glaciers is primarily believed to reduce surface albedo, resulting in greater melt and mass loss. However, no study has yet included the effects of biological activity in albedo reduction models. Here, we provide the first experimental evidence that microbial activity can significantly decrease glacier surface albedo. Indeed, the addition of nutrients at ice meltwater concentrations to microbe-impurity mixtures resulted in extensive microbial organic carbon fixation and accumulation in Greenland Ice Sheet surface debris. Accumulated organic carbon, over the period of a melt season, darkened the glacial debris in our experiments from $31.1 \%$ to $15.6 \%$ surface reflectivity (used as an analogue for albedo in our calculations), generating a strongly absorbing surface. Our experiments are the first to quantify the microbially-induced potential melt increase for the Greenland Ice Sheet (up to an average of $17.3 \pm 2.5 \mathrm{Gt} \mathrm{yr}^{-1}$ at present and up to $\sim 85 \mathrm{Gt} \mathrm{yr}^{-1}$ by 2100 , based on our first order calculations). Mass loss from glaciers will conceivably intensify through enhanced microbial activity, resulting from longer melt seasons and fertilisation from anthropogenic sources.

Received 8 October 2015 | Accepted 27 January 2016 | Published 11 March 2016

\section{Introduction}

Glacier surfaces melt primarily by the absorption of solar radiation, which depends on the surface albedo (Boggild et al., 2010; Box et al., 2012). Albedo is affected by the physical properties of snow and ice, such as the geometric pattern of the snow surface (Pirazzini, 2004), snow metamorphism (Nakamura et al.,

1. Bristol Glaciology Centre, School of Geographical Sciences, University of Bristol, Bristol BS8 1SS, UK Currentaddress Výskumný ústav potravinársky - NPPC and Slovak Organisation for Space Activities (SOSA), Bratislava, Slovakia

Corresponding author (email: michaela.musilova@community.isunet.edu)

3. Department of Earth Sciences, Graduate School of Science, Chiba University, 1-33, Yayoicho, Inage-ku, Chiba-city, Chiba, 263-8522, Japan

2001), water content (Ryser et al., 2013) and particulate impurities on the glacie surface (Paterson, 1994). Most studies assume that the accumulation of inorganic and organic particulates, such as anthropogenic and naturally occurring black carbon (Doherty et al., 2013), volcanic ash and dust (Dumont et al., 2014), are key drivers of the darkening and reduction of the ice albedo.

Recent research shows that there is high microbial activity on glacial surfaces (Anesio et al., 2009), some associated with pigmented algae, which absorb significantly more light than local inorganic dust particles on the Greenland Ice Sheet (GrIS) (Lutz et al., 2014). Furthermore, microbially-rich glacier surface debris (cryoconite) reduces the glacier surface (supraglacial) albedo (Takeuchi et al., 2001). Cryoconite accumulates in water-filled holes on glacier surfaces, causing enhanced melting around the deposited sediment (Fountain et al., 2004) These so-called cryoconite holes contain a substantial amount of organic matter (5-10 \%; Takeuchi et al., 2001), with values often $>6 \%$ organic carbon (OC) on GrIS (Stibal et al., 2010). Microbial activity is believed to cause a further darkening of the already dark inorganic particulates in cryoconite debris by producing and/or transforming OC (Anesio et al., 2009; Hodson et al., 2010a). Microbes are thought to decompose more labile OC to form dark-coloured humic substances (Takeuchi et al., 2001) and to produce extracellular polymeric substances (EPS) (Hodson et al., 2010b). These glue-like compounds help cement organic and inorganic particles (including black carbon; Stibal et al., 2012a) into granules, thereby increasing their residence time on glacier surfaces (Hodson et al., 2010b Langford et al., 2010). This can lead to a significant decrease in supraglacial albedo, considering cryoconite debris covers $0.1-10 \%$ of the ablation zone of glaciers in the Northern Hemisphere (Hodson et al., 2007; Anesio et al., 2009; Hodson et al., 2010a).

"We conducted an original laboratory experiment, the 'cryoconite casserole', to investigate the darkening of cryoconite debris as a result of OC accumulation driven by microbial activity. Greenlandic cryoconite debris (10 \% natural cryoconite, mixed with $90 \%$ cryoconite furnaced at $550{ }^{\circ} \mathrm{C}$ to remove all organic matter) was exposed to simulated Greenlandic summer conditions, in terms of temperature, lighting and nutrient availability (see Methodology in the Supplementary Information for full details). This cryoconite mixture simulated the early stages of cryoconite hole development, where the debris is mostly inorganic and it can become colonised by local microbial communities. Samples were kept either under 'light' (simulated daylight) or 'dark' (covered in aluminium foil) conditions. Three different water/nutrient applications were made: 1) blank, sterile water, 2) nitrogen $(\mathrm{N})$ and phosphorous $(\mathrm{P})$ additions and 3) N, P and organic carbon (C) additions. The nutrient additions simulated concentrations released from ice melt (Stibal et al., 2012b; Telling et al., 2012; Lawson et al., 2014). All light and nutrient treatments had five replicates. Cryoconite casserole samples were analysed for their nutrient composition, surface reflection normal to the ice surface in the laboratory and chlorophyll $a$ (chla) concentration. The structure of the debris was observed with an optical and fluorescent microscope. Here, we present data collected at the end of one and three consecutive simulated summer seasons 
(the latter was performed to confirm the results observed during the one simulated summer experiment). The reduction of surface reflection due to biological activity, derived from our results, was used as a proxy for a reduction in albedo in the regional climate model Modèle Atmosphérique Régional (MAR; Fettweis et al., 2013) to project future microbially-mediated increases in GrIS melt (see Methodology, Supplementary Information).

\section{Results and Discussion}

Supraglacial Microbial Nutrient Production and Recycling. Substantial amounts of OC $(\sim 1.7 \pm 0.5 \mathrm{mg}$ OC/g of cryoconite) were produced and accumulated by microbes over the course of one simulated summer in 'light' conditions with NPC additions (Fig. 1a), compared to 'dark' and blank samples. OC concentrations quadrupled $(7.0 \pm 0.9 \mathrm{mg} \mathrm{OC} / \mathrm{g}$ of cryoconite) when the samples were exposed to three consecutive simulated summers (Fig. 1b). The total $\mathrm{C}$ addition was only $0.25 \%$ of the final accumulated OC. Thus nearly all accumulated OC in this treatment originated from microbial $\mathrm{C}$ fixation/transformation.

'Light' treatments with NPC additions also generated the highest concentrations of particulate organic nitrogen (PON; $100.4 \pm 26.7 \mu \mathrm{g}$ PON/g cryoconite) and organic bound phosphorous (OP; $19.5 \pm 6.4 \mu \mathrm{g}$ OP/g cryoconite) (Table 1). By contrast, PON and OP were consumed in the dark NP treatments $(6.6 \pm 4.4 \mu \mathrm{g}$ $\mathrm{PON} / \mathrm{g}$ cryoconite and $22.0 \pm 1.7 \mu \mathrm{g} \mathrm{OP} / \mathrm{g}$ cryoconite, respectively, after one season). Additionally, the light samples with NPC additions had the biggest decrease in inorganic bound phosphorous (IP; $27.2 \pm 5.4 \mu \mathrm{g} \mathrm{IP/g}$ cryoconite consumed), with respect to the starting IP concentrations. This is indicative of an uptake of $\mathrm{P}$ from the sediment, as a consequence of microbial fixation of OC. The concentrations of PON and OP increased 7-fold and 4-fold, respectively, for the same samples ('light' with NPC additions) after three simulated summers (Table 1).

The amount of OC produced and accumulated in our experiments simulating glacial surfaces was disproportionate compared to the amounts of $\mathrm{C}, \mathrm{N}$ and $\mathrm{P}$ added to the samples at ice meltwater concentrations. $\mathrm{P}$ concentrations were derived using the Redfield ratio C:N:P of 106:6:1 (Redfield, 1958), while keeping $\mathrm{N}$ and $\mathrm{C}$ concentrations within the range of concentrations detected in GrIS ice melt (Stibal et al., 2012b; Telling et al., 2012; Lawson et al., 2014). Therefore, the experimental set-up provided a realistic scenario for the potential accumulation of organic matter at the surface of glaciers. Nevertheless, the ratio of the organic C:N:P fixed in this experiment was 93:5:1, over one simulated summer, and 90:9:1, over three simulated summers. These ratios are comparable to others reported in cold, high latitude regions (Stibal et al., 2008; Martiny et al., 2013). Cryoconite fertilisation with ambient nutrient conditions (NP and NPC additions) appears to produce a response of self-organisation: $\mathrm{P}$ mining out of sediment, autocatalytic $\mathrm{N}_{2}$ fixation and significant $\mathrm{OC}$ fixation. The $\mathrm{N}_{2}$ fixation was most probably performed by cyanobacteria species belonging to the Nostocaceae family, whose

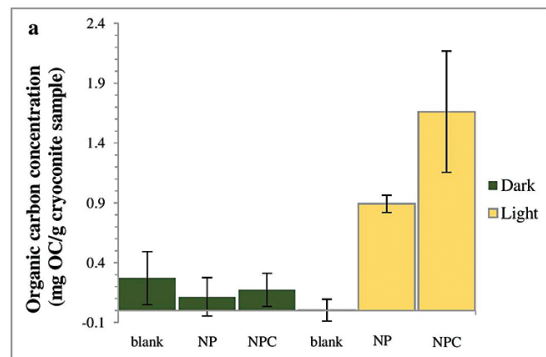

Nutrient treatments

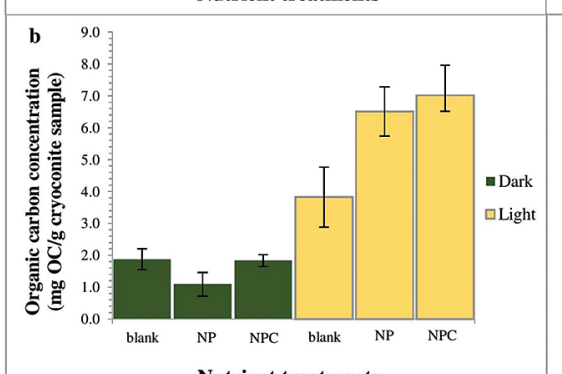

Nutrient treatments

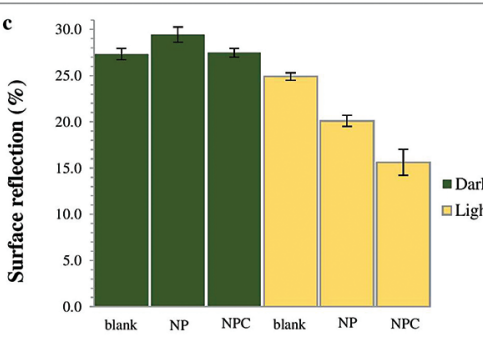

Nutrient treatments

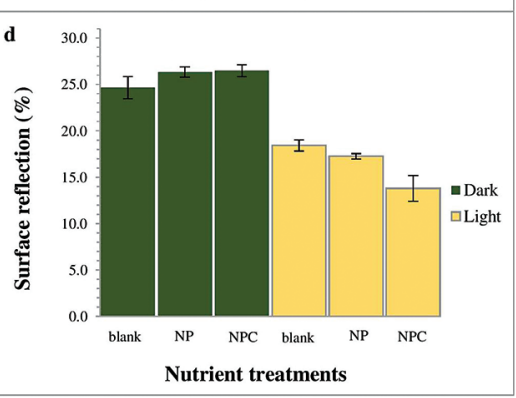

igure 1 OC accumulated over (a) one simulated summer season and (b) over three simulated summer seasons. Surface reflection after (c) one simulated summer season and (d) three simulated summer seasons. 'Light' samples accumulated significantly more OC compared to 'dark' samples (two-way ANOVA $p<0.05$ in (a) and $p<0.001$ in (b)). This was accompanied by a decrease in cryoconite sediment reflectivity by $\sim 15.5$ percentage points, from a startin $31.1 \%$, for the 'light' with NPC treatment samples in (c) and a further 1.8 percentage points in (d). Two-way ANOVA analyses showed a significant difference in spectral reflection between 'light' and 'dark' samples $(p<0.001)$, nutrient conditions $(p<0.001)$ and the interaction of nutrient and light settings $(p<0.01)$. There was a significant difference $(p<0.001)$ between samples NPC and blanks, NCP and NP $(p<0.05)$ and NP and blanks $(p<0.05)$, using Turkey Post-hoc analyses in (c-d). Standard errors were calculated as $1 \sigma(n=5)$.

16S rRNA and N fixation functional genes have been found within Arctic and Antarctic cryoconite (Cameron et al., 2012a,b). Phosphorous limitation was previously reported in glacial environments (Mindl et al., 2007; Stibal et al., 2009), while $\mathrm{N}$ limitation was shown to stimulate $\mathrm{N}_{2}$ fixation on glaciers (Telling et al., 2011). Supraglacial microbial activity can thus be a vital source of bioavailable nutrients for subglacial and downstream environments.

We hypothesise that adding $\mathrm{C}$ as bioavailable carbohydrate, at ambient concentrations, has a kinetic effect on the heterotrophic microbial community, speeding up the recycling of other organic matter. Dependence on labile OC additions demonstrates the importance of heterotrophic processes (recycling nutrients), acting in concert with autotrophic processes (fixing and accumulating $\mathrm{OC}$ ), in the maintenance of self-organised supraglacial microbial communities. Blank and 'dark' samples receiving no nutrients initially showed no significant 
Table 1 Concentrations of PON, OP, IP and chla for each light and nutrient treatment, over one and three simulated summer seasons. The concentrations are the differences between the final and starting concentrations in each treatment. Significant differences (two-way ANOVA) are indicated between (a) 'light' and 'dark' samples, (b) nutrient treatments and (c) the interaction of nutrient and light settings.

\begin{tabular}{|c|c|c|c|c|c|c|c|c|}
\hline \multirow{2}{*}{\multicolumn{2}{|c|}{ Sample conditions }} & \multicolumn{3}{|c|}{ Light } & \multicolumn{3}{|c|}{ Dark } & \multirow{3}{*}{\begin{tabular}{|c}
$\begin{array}{c}\text { Two-way } \\
\text { ANOVA } \\
\text { analysis: }\end{array}$ \\
$\mathrm{a}(\mathrm{p}<0.01)$
\end{tabular}} \\
\hline & & \multirow{2}{*}{$\begin{array}{c}\begin{array}{c}\text { Sterile } \\
\text { water }\end{array} \\
\begin{array}{c}11.7 \\
\pm 3.8\end{array}\end{array}$} & \multirow{2}{*}{\begin{tabular}{|c|}
$\begin{array}{c}\mathrm{N} \text { and } \mathrm{P} \\
\text { additions }\end{array}$ \\
$\begin{array}{c}32.6 \\
\pm 21.4\end{array}$
\end{tabular}} & \multirow{2}{*}{\begin{tabular}{|c|}
$\begin{array}{c}\text { N, P } \\
\text { and C } \\
\text { additions }\end{array}$ \\
100.4 \\
\pm 26.7 \\
\end{tabular}} & \multirow{2}{*}{\begin{tabular}{|c|}
$\begin{array}{c}\text { Sterile } \\
\text { water }\end{array}$ \\
-3.1 \\
\pm 6.0 \\
\end{tabular}} & \multirow{2}{*}{\begin{tabular}{|c|}
$\mathbf{N}$ and $\mathrm{P}$ \\
additions
\end{tabular}} & \multirow{2}{*}{\begin{tabular}{|c|}
$\begin{array}{c}\mathrm{N}, \mathrm{P} \\
\text { and C } \\
\text { additions }\end{array}$ \\
$\begin{array}{c}-2.4 \\
\pm 10.2\end{array}$ \\
\end{tabular}} & \\
\hline \multirow{4}{*}{ 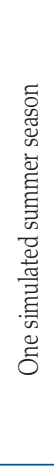 } & $\begin{array}{c}\text { PON concentration } \\
(\mu g \text { PON/g } \\
\text { cryoconite sample) }\end{array}$ & & & & & & & \\
\hline & $\begin{array}{l}\text { OP concentration } \\
\text { (ug OC/g cryoconite } \\
\text { sample) }\end{array}$ & $\begin{array}{l}-2.1 \\
\pm 9.6\end{array}$ & $\begin{array}{l}13.4 \\
\pm 6.0\end{array}$ & $\begin{array}{l}19.5 \\
\pm 6.4\end{array}$ & $\begin{array}{l}-21.9 \\
\pm 1.8\end{array}$ & $\begin{array}{c}-22 \\
\pm 1.7\end{array}$ & $\begin{array}{l}-10 \\
\pm 7.1\end{array}$ & $\begin{array}{l}\mathrm{a}(\mathrm{p}<0.001) \\
\mathrm{b}(\mathrm{p}<0.05)\end{array}$ \\
\hline & 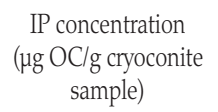 & $\begin{array}{l}-3.9 \\
\pm 5.5\end{array}$ & $\begin{array}{c}-22 \\
\pm 9.8\end{array}$ & $\begin{array}{l}-27.2 \\
\pm 5.4\end{array}$ & $\begin{array}{r}16.9 \\
\pm 8.5\end{array}$ & $\begin{array}{c}23.6 \\
\pm 10.4\end{array}$ & $\begin{array}{l}12.5 \\
\pm 2.4\end{array}$ & $\mathrm{a}(\mathrm{p}<0.001)$ \\
\hline & $\begin{array}{l}\text { Chla concentration } \\
\text { (in } \mu g \text { of chla/g } \\
\text { of sample) }\end{array}$ & $\begin{array}{c}1.6 \\
\pm 0.2\end{array}$ & $\begin{array}{c}3.1 \\
\pm 0.1\end{array}$ & $\begin{array}{c}3.8 \\
\pm 0.2\end{array}$ & $\begin{array}{c}1 \\
\pm 0.1\end{array}$ & $\begin{array}{c}1.1 \\
\pm 0.1\end{array}$ & $\begin{array}{c}1.1 \\
\pm 0.0\end{array}$ & $\begin{array}{l}\mathrm{a}(\mathrm{p}<0.001) \\
\mathrm{b}(\mathrm{p}<0.01) \\
\mathrm{c}(\mathrm{p}<0.01)\end{array}$ \\
\hline \multirow{4}{*}{ 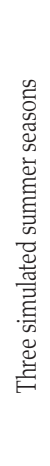 } & $\begin{array}{l}\text { PON concentration } \\
\text { (pg PON/g } \\
\text { cryoconite sample) }\end{array}$ & $\begin{array}{l}149.6 \\
\pm 31.7\end{array}$ & $\begin{array}{l}253.4 \\
\pm 42.9\end{array}$ & $\begin{array}{l}680.5 \\
\pm 51.1\end{array}$ & $\begin{array}{c}51.2 \\
\pm 19.2\end{array}$ & $\begin{array}{c}67.3 \\
\pm 14.2\end{array}$ & $\begin{array}{c}61.4 \\
\pm 18.1\end{array}$ & $\begin{array}{l}\mathrm{a}(\mathrm{p}<0.001) \\
\mathrm{b}(\mathrm{p}<0.001) \\
\mathrm{c}(\mathrm{p}<0.001)\end{array}$ \\
\hline & $\begin{array}{c}\text { OP concentration } \\
\text { (ug OC/g cryoconite } \\
\text { sample) }\end{array}$ & $\begin{array}{l}27.7 \\
\pm 8.9\end{array}$ & $\begin{array}{l}35.6 \\
\pm 9.1\end{array}$ & $\begin{array}{c}85.4 \\
\pm 13.6\end{array}$ & $\begin{array}{l}15.2 \\
\pm 0.9\end{array}$ & $\begin{array}{l}13.6 \\
\pm 1.4\end{array}$ & $\begin{array}{l}16.3 \\
\pm 4.5\end{array}$ & $\begin{array}{l}\mathrm{a}(\mathrm{p}<0.001) \\
\mathrm{b}(\mathrm{p}<0.001) \\
\mathrm{c}(\mathrm{p}<0.01)\end{array}$ \\
\hline & $\begin{array}{c}\text { IP concentration } \\
\text { (g OC/g cryoconite } \\
\text { sample) }\end{array}$ & $\begin{array}{l}-35.6 \\
\pm 9.4\end{array}$ & $\begin{array}{r}-46.7 \\
\pm 13.5\end{array}$ & $\begin{array}{l}-97.7 \\
\pm 15.1\end{array}$ & $\begin{array}{l}-21.8 \\
\pm 6.3\end{array}$ & $\begin{array}{l}-24.1 \\
\pm 5.2\end{array}$ & $\begin{array}{l}-19.6 \\
\pm 7.3\end{array}$ & $\begin{array}{l}\mathrm{a}(\mathrm{p}<0.001) \\
\mathrm{b}(\mathrm{p}<0.01) \\
\mathrm{c}(\mathrm{p}<0.01)\end{array}$ \\
\hline & $\begin{array}{l}\text { Chla concentration } \\
\text { (in } \mu g \text { of chla/g of } \\
\text { sample) }\end{array}$ & $1.5 \pm 0.2$ & $2.0 \pm 0.0$ & $4.0 \pm 0.5$ & $1.0 \pm 0.1$ & $1.1 \pm 0.2$ & $1.1 \pm 0.0$ & $\begin{array}{l}\mathrm{a}(\mathrm{p}<0.001) \\
\mathrm{b}(\mathrm{p}<0.001) \\
\mathrm{c}(\mathrm{p}<0.001)\end{array}$ \\
\hline
\end{tabular}

OC accumulation. However, even these samples showed substantial amounts of OC accumulation after three simulated summer seasons. The blank samples may have simply needed a longer period of time for autotrophic processes to dominate in the microbial community. We postulate that chemolithotrophic activity is the likely explanation for the small OC accumulation in the dark samples.

Impacts of Microbial Activity on Glacial Ice Reflectivity and Calculated Melt Rates. There was a strong negative correlation between OC accumulation and surface reflection (Pearson's $r=-0.897, p<0.05$ ). The accumulation of microbially-produced OC caused a significant reduction of $\sim 15.5$ percentage points in the cryoconite's reflectivity in the 'light' with NPC treatment samples, from a starting $31.1 \%$, over the one simulated summer (Fig. 1c). It decreased by a further 1.8 percentage points after three simulated summers (Fig. 1d). This is most likely a result of the cryoconite material becoming darker through microbial OC production, accumulation and OC decomposition into dark-coloured humic substances. Microbial activity had the greatest effect in reducing the cryoconite material's surface reflectivity over the first simulated summer. Afterwards, the surface reflectivity of the cryoconite-organic material mixture probably approached a plateau, since further microbial activity and OC accumulation led to only a slight additional reduction in its surface reflectivity after three simulated summers. Additionally, there was a strong correlation between the chla concentration and OC accumulation across all treatments (Table 1, Fig. 1) (Pearson's $r=0.934, p<0.01)$. Cyanobacterial sediment granules only developed in 'light' samples with nutrient additions, after one simulated summer (Fig. 2), which also experienced a substantial decrease in reflectivity. Conversely, blank samples only contained sediment granules after three simulated summers. Furthermore, dark and round microbial cell clusters were predominant in the samples with cyanobacterial granule development. These were most likely colonies of cyanobacteria, such as Oscillatoriales and Nostocales, previously observed in Greenlandic cryoconite (Cameron et al., 2012b; Stibal et al., 2012b). They may have further contributed to the darkening of the samples' reflectivity. Similar cyanobacterial granules can be found in supraglacial cryoconite holes around the world under in situ conditions (Hodson et al., 2010b; Langford et al., 2010). The granules form partially by microbial EPS excretion (Hodson et al., 2010b; Langford et al., 2010), which we suggest enables more nutrient and particle retention within the cryoconite. Further OC fixation and transformation is, therefore, likely to occur in the cryoconite granules, ultimately leading to the darkening of glacial cryoconite sediment. Over longer periods of time, larger cryoconite aggregations will melt into the surface ice to form cryoconite holes, which are more stable environments for organic matter accumulation. However, in the short term, new cryoconite on glaciers undergoes an important decrease in albedo. The increase in anthropogenic $\mathrm{NO}_{3}{ }^{-}$deposition on glaciers (Lyons et al., 1990; Duderstadt et al., 2014) has been reported to reduce the microbial $\mathrm{N}$ limitation in cryoconite habitats (Telling et al., 2011). Enhanced anthropogenic $\mathrm{NO}_{3}{ }^{-}$input will likely lead to a significant decrease in $\mathrm{N}_{2}$ fixation, allowing more bio-energy to be available for $\mathrm{C}$ fixation. Consequently, we envisage that there would be a rise in OC production within cryoconite debris, causing considerable albedo reduction, and thus mass loss on glaciers and ice sheets covered in cryoconite.

We calculated the maximum microbially-mediated GrIS potential melt to be on average $17.3 \pm 2.5 \mathrm{Gt} \mathrm{yr}^{-1}$, using the observed 15.5 percentage point decrease in the debris surface reflection (see Methodology, Supplementary Information). This is about $5 \%$ of the present day runoff (Bamber et al., 2012). The estimate is based on a $10 \%$ debris cover concentration, over the extent of GrIS that undergoes persistent melting (more than 1-10 days/yr). The uncertainty in additional melt includes contributions due to the albedo and debris cover, but not any uncertainty in future climate projections. It is, therefore, a first order estimate. 


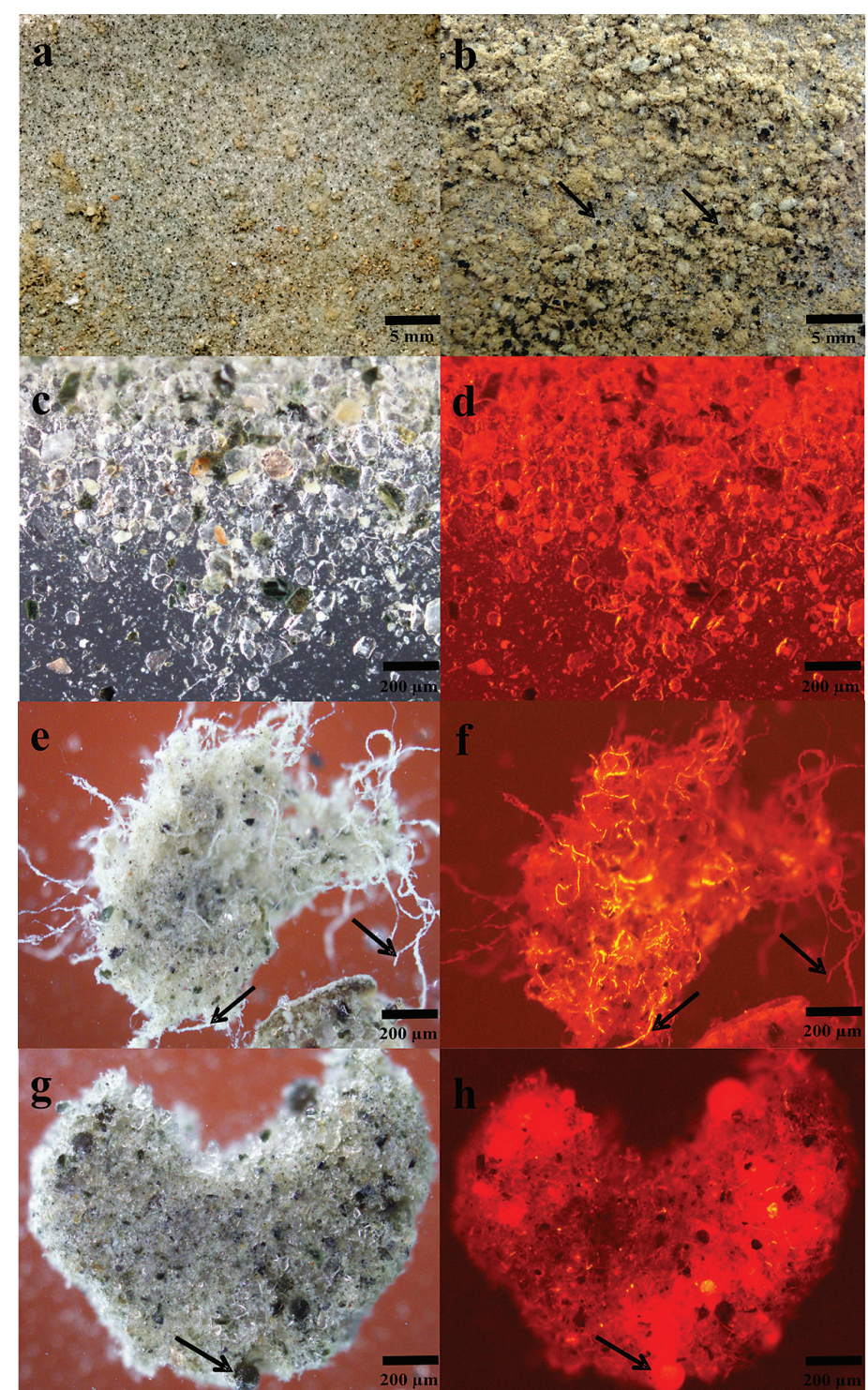

Figure 2 Microbial granule development in 'light' samples with nutrient additions. Images (a-c), (e) and (g) were taken using optical microscopy. Autofluorescence microscopy was performed to visualise photosynthetic autotrophs in images (d), (f) and (h). The initial mixture of inorganic dust with $10 \%$ natural cryoconite (a and c) developed into samples rich in granule and filamentous cyanobacteria (b, e-h). Examples of cyanobacterial filaments and colonie (resembling black spheres) are indicated by arrows in images (b), (e-h)
With the projected changing climate, the GrIS melt area is estimated to expand from the present day $31 \%$ of the total ice sheet (Fig. 3a), to $65 \%$ (Fig. 3b) and $92 \%$ (Fig. 3c) by 2100. These projections are based on two representative greenhouse gas concentration pathways (RCP) 4.5 and 8.5. The former is associated with moderate increases in greenhouse gas concentrations, while the latter is closer to a 'business as usual' trajectory. The effect will be proportionally larger in small Alpine and Arctic valley glaciers, since the melt areas could cover up to $100 \%$ of the glaciers by 2100 (see Methodology, Supplementary Information) The GrIS biologically-induced melt potential could therefore increase up to 42 and $85 \mathrm{Gt} \mathrm{yr}^{-1}$, for RCP 4.5 and 8.5, respectively. These calculations assume no change in $\mathrm{NO}_{3}$ - concentrations and are, therefore, likely a conservative estimate. Furthermore, other ice surface organisms, such as algae (Yallop et al., 2012; Lutz et al., 2014), will likely significantly increase the overall biologically-induced melt potential calculated for cryoconite cyanobacteria in this study. The biological impact on albedo hence plays an important role in modulating mass loss from glacier surfaces and must be included in albedo models to capture adequately the evolving properties of glaciers in a changing climate. Additionally, it is postulated that the warming climate will likely extend melt seasons, leading to increases in biological activity and thus contributing further to the darkening of glaciers and ice sheets (Benning et al., 2014).
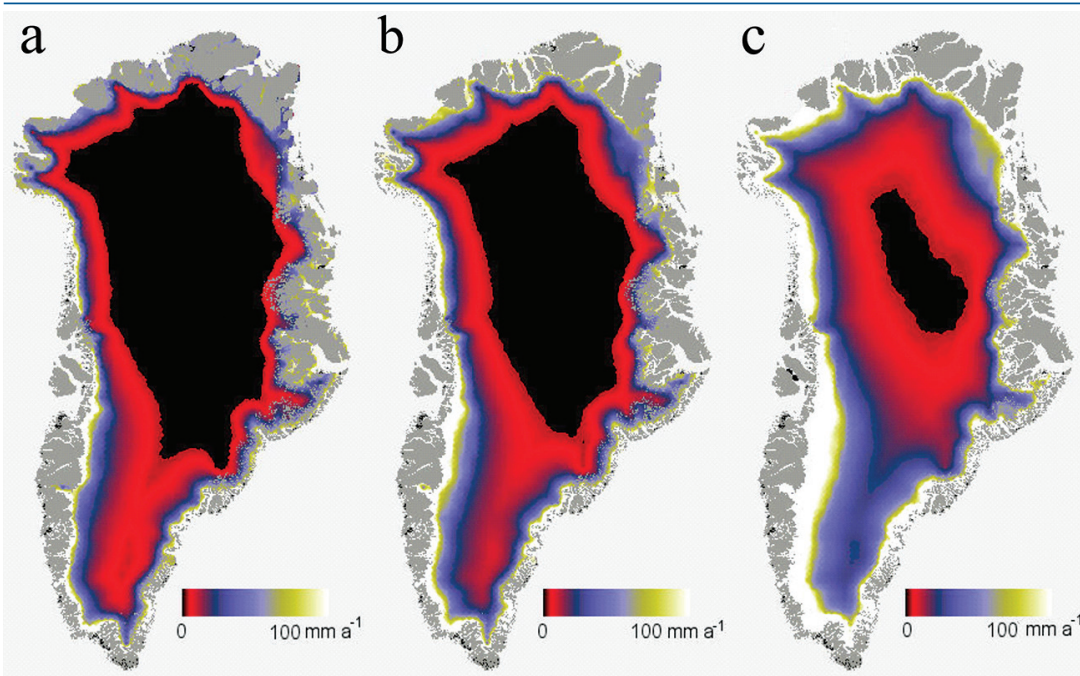

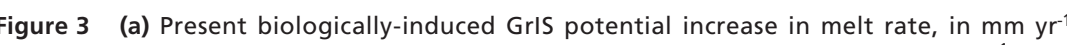

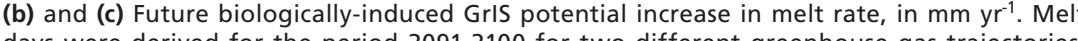
days were derived for the period 2091-2100 for two different greenhouse gas trajectories, RCP4.5 (b) and RCP8.5 (c). 
In conclusion, this study provided for the first time a first-order estimate of the effect of microbial activity on glacial albedo and melt for the GrIS. This effect was significant enough to merit inclusion in albedo models for the GrIS and other glacial environments around the world. In future more elaborate models, other factors (such as the latitudinal variability in PAR; differences between surface reflection and albedo measurements, in the field and in the laboratory; and the influence of surface glacial flow and wind on microbial cryoconite communities) would need to be included to provide a more accurate upscaling of the calculations to the entire GrIS.

\section{Acknowledgements}

This study was funded by grants from the UK National Environment Research Council (NERC; NE/J02399X/1 to Anesio and NERC Doctoral Training Programme Grant to Musilova) and the Royal Society International Exchanges Scheme to Anesio and Takeuchi.

Editor: Eric H. Oelkers

\section{Author Contributions}

M.M. and A.M.A designed the overall study. M.T. and N.T. were involved in advising the detail of the study design. J.B. performed the climate model simulations. M.M. performed the experiment, collected and processed the data, and wrote the paper. All authors discussed the results and commented on the manuscript.

\section{Additional Information}

Supplementary Information accompanies this letter at www.geochemicalperspectivesletters.org/article1611

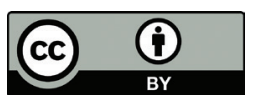

This work is distributed under the Creative Commons Attribution 4.0 License, which permits unrestricted use, distribution, and reproduction in any medium, provided the original author and source are credited. Additional information is available at http://www. geochemicalperspectivesletters.org/copyright-and-permissions.

Cite this letter as: Musilova, M., Tranter, M., Bamber, J.L., Takeuchi, N., Anesio, A.M. (2016) Experimental evidence that microbial activity lowers the albedo of glaciers. Geochem. Persp. Let. 2, 106-116.

\section{References}

Anesio, A.M., Hodson, A.J., Fritz, A., Psenner, R., SAttler, B. (2009) High microbial activity on glaciers: importance to the global carbon cycle. Global Change Biology 15, 955-960.

Bamber, J., van den Broeke, M., Ettema, J., Lenaerts, J., Rignot, E. (2012) Recent large increases in freshwater fluxes from Greenland into the North Atlantic. Geophysical Research Letters 39, doi: 10.1029/2012GL052552.

Benning, L.G., Anesio, A.M., LuTZ, S., Tranter, M. (2014) Biological impact on Greenland's albedo. Nature Geoscience 7, 691-691.

BogGiLD, C.E., BRANDT, R.E., BRown, K.J., WarRen, S.G. (2010) The ablation zone in northeast Greenland: ice types, albedos and impurities. Journal of Glaciology 56, 101-113.

Box, J.E., Fettweis, X., Stroeve, J.C., Tedesco, M., Hall, D.K., Steffen, K. (2012) Greenland ice sheet albedo feedback: thermodynamics and atmospheric drivers. Cryosphere 6, 821-839.

CAmeron, K.A., Hodson, A.J., Osborn, A.M. (2012a) Carbon and nitrogen biogeochemical cycling potentials of supraglacial cryoconite communities. Polar Biology 35, 1375-1393.

CAMERON, K.A., HODSON, A.J., OsBORN, A.M. (2012b) Structure and diversity of bacterial, eukaryotic and archaeal communities in glacial cryoconite holes from the Arctic and the Antarctic. Fems Microbiology Ecology 82, 254-267.

Doherty, S.J., Grenfell, T.C., Forsstrom, S., HegG, D.L., Brandt, R.E., Warren, S.G. (2013) Observed vertical redistribution of black carbon and other insoluble light-absorbing particles in melting snow. Journal of Geophysical Research-Atmospheres 118, 5553-5569.

Duderstadt, K.A., Dibb, J.E., Jackman, C.H., Randall, C.E., Solomon, S.C., Mills, M.J. SCHWADRON, N.A., SPENCE, H.E. (2014) Nitrate deposition to surface snow at Summit, Greenland, following the 9 November 2000 solar proton event. Journal of Geophysical ResearchAtmospheres 119, 6938-6957.

Dumont, M., Brun, E., Picard, G., Michou, M., Libois, Q., Petit, J.R., Geyer, M., Morin, S Josse, B. (2014) Contribution of light-absorbing impurities in snow to Greenland's darkening since 2009. Nature Geoscience 7, 509-512.

Fettweis, X., Franco, B., Tedesco, M., van Angelen, J.H., Lenaerts, J.T.M., van den Broeke, M.R., GALLEE, H. (2013) Estimating the Greenland ice sheet surface mass balance contribution to future sea level rise using the regional atmospheric climate model MAR. Cryosphere 7, 469-489.

Fountain, A.G., Tranter, M., Nylen, T.H., Lewis, K.J., Mueller, D.R. (2004) Evolution of cryoconite holes and their contribution to meltwater runoff from glaciers in the McMurdo Dry Valleys, Antarctica. Journal of Glaciology 50, 35-45.

Hodson, A., Anesio, A.M., NG, F, Watson, R., Quirk, J., IRvine-FYnn, T., DYe, A., Clark, C., McCloy, P., KoHler, J., SATTLER, B. (2007) A glacier respires: Quantifying the distribution and respiration $\mathrm{CO}_{2}$ flux of cryoconite across an entire Arctic supraglacial ecosystem. Journal of Geophysical Research-Biogeosciences 112, doi: 10.1029/2007JG000452.

Hodson, A., Boggild, C., Hanna, E., Huybrechts, P., Langford, H., Cameron, K., HouldSWORTH, A. (2010a) The cryoconite ecosystem on the Greenland ice sheet. Annals of Glaciology $51,123-129$.

Hodson, A., Cameron, K., Boggild, C., Irvine-Fynn, T., Langford, H., Pearce, D, BANWART, S. (2010b) The structure, biological activity and biogeochemistry of cryoconite aggregates upon an Arctic valley glacier: Longyearbreen, Svalbard. Journal of Glaciology 56, 349-362.

LANGFord, H., Hodson, A., BANWART, S., BoggiLd, C. (2010) The microstructure and biogeochemistry of Arctic cryoconite granules. Annals of Glaciology 51, 87-94. 
Lawson, E.C., Wadham, J.L., Tranter, M., Stibal, M., Lis, G.P., Butler, C.E.H., Laybourn Parry, J., Nienow, P., Chandler, D., Dewsbury, P. (2014) Greenland Ice Sheet exports labile organic carbon to the Arctic oceans. Biogeosciences 11, 4015-4028.

LutZ, S., ANESIO, A.M., VillaR, S.E.J., BenNing, L.G. (2014) Variations of algal communities cause darkening of a Greenland glacier. Fems Microbiology Ecology 89, 402-414.

Lyons, W.B., MAYeWski, P.A., SPEncer, M.J., TwICKLER, M.S. (1990) Nitrate Concentrations in Snow from Remote Areas - Implication for the Global Nox Flux. Biogeochemistry 9, 211-222.

Martiny, A.C., Pham, C.T.A., Primeau, F.W., VRugt, J.A., Moore, J.K., Levin, S.A., Lomas, M.W. (2013) Strong latitudinal patterns in the elemental ratios of marine plankton and organic matter. Nature Geoscience 6, 279-283.

Mindl, B., Anesio, A.M., Meirer, K., Hodson, A.J., Laybourn-Parry, J., Sommaruga, R, SATTLER, B. (2007) Factors influencing bacterial dynamics along a transect from supraglacial runoff to proglacial lakes of a high Arctic glacier. Fems Microbiology Ecology 59, 307-317.

Nakamura, T., Abe, O., Hasegawa, T., Tamura, R., Ohta, T. (2001) Spectral reflectance of snow with a known grain-size distribution in successive metamorphism. Cold Regions Science and Technology 32, 13-26.

PAterson, W.S.B. (1994) The physics of glaciers. Elsevier, Oxford, 480 pp.

PIRAZZINI, R. (2004) Surface albedo measurements over Antarctic sites in summer. Journal of Geophysical Research-Atmospheres 109, doi: 10.1029/2004JD004617.

Redfield, A.C. (1958) The Biological Control of Chemical Factors in the Environment. American Scientist 46, 205-221.

Ryser, C., Luthi, M., Blindow, N., Suckro, S., Funk, M., Bauder, A. (2013) Cold ice in the ablation zone: Its relation to glacier hydrology and ice water content. Journal of Geophysical Research-Earth Surface 118, 693-705.

Stibal, M., Tranter, M., Telling, J., Benning, L.G. (2008) Speciation, phase association and potential bioavailability of phosphorus on a Svalbard glacier. Biogeochemistry 90, 1-13.

Stibal, M., Anesio, A.M., Blues, C.J.D., Tranter, M. (2009) Phosphatase activity and organic phosphorus turnover on a high Arctic glacier. Biogeosciences 6, 913-922

Stibal, M., LaWson, E.C., Lis, G.P., MaK, K.M., Wadham, J.L., Anesio, A.M. (2010) Organic matter content and quality in supraglacial debris across the ablation zone of the Greenland ice sheet. Annals of Glaciology 51, 1-8.

StibAL, M., SABACKA, M., ZARSKY, J. (2012a) Biological processes on glacier and ice sheet surfaces. Nature Geoscience 5, 771-774.

Stibal, M., Telling, J., CoOK, J., MaK, K.M., Hodson, A., Anesio, A.M. (2012b) Environmental Controls on Microbial Abundance and Activity on the Greenland Ice Sheet: A Multivariate Analysis Approach. Microbial Ecology 63, 74-84.

TAKEUCHI, N., KoHSHIMA, S., SeKO, K. (2001) Structure, formation, and darkening process of albedo-reducing material (cryoconite) on a Himalayan glacier: A granular algal mat growing on the glacier. Arctic Antarctic and Alpine Research 33, 115-122.

Telling, J., Anesio, A.M., Tranter, M., Irvine-Fynn, T., Hodson, A., Butler, C., Wadham, J. (2011) Nitrogen fixation on Arctic glaciers, Svalbard. Journal of Geophysical Research-Biogeosciences 116, doi: 10.1029/2010JG001632.

Telling, J., Stibal, M., Anesio, A.M., Tranter, M., Nias, I., Cook, J., Bellas, C., Lis, G., Wadham, J.L., Sole, A., NienOW, P., HODSON, A. (2012) Microbial nitrogen cycling on the Greenland Ice Sheet. Biogeosciences 9, 2431-2442.

Yallop, M.L., Anesio, A.M., Perkins, R.G., Cook, J., Telling, J., Fagan, D., MacFarlane, J Stibal, M., Barker, G., Bellas, C., Hodson, A., Tranter, M., Wadham, J., Roberts, N.W. (2012) Photophysiology and albedo-changing potential of the ice algal community on the surface of the Greenland ice sheet. Isme Journal 6, 2302-2313. 